\title{
The Space of Collapse: A two-part terrain
}

\author{
Jane Madsen
}

\section{Introduction}

Taking as a starting point Heinrich von Kleist's empirical observation that an arch remains standing because the stones all want to collapse at the same time, this paper analyses ideas of collapse as history, architecture, material and concept. The image of collapse became a recurrent trope in Kleist's writing. After reading Kant's critical philosophy, Kleist made a traumatic transition from empirical to critical thinking. Following the 1755 earthquake in Lisbon, Kant concentrated on inquiry into natural phenomena; this was a decisive moment for the progression of his critical thinking effecting a transition from natural to critical philosophy. Focusing on the site of Portland in Dorset, United Kingdom, and the eighteenth-century ideas of geological mapping used to record it, I read the site as a demonstration of Kleist's notions of immanent and actual collapse. I argue that at Portland the material histories of place and the histories of material are traced on to constructed, empty spaces as a disrupted landscape of collapse. Occurring in the late eighteenth and early nineteenth centuries, these two terrains demonstrate collapse as material for modernist thought.

\section{The first terrain}

\section{Kant and Kleist: Earthquake and architectures of collapse}

I was walking back to the city, lost in my own thoughts, through an arched gate. Why I asked myself, does this arch not collapse, since after all it has no support? It remains standing, I answered, because all the stones tend to collapse at the same time... ${ }^{1}$

Heinrich von Kleist, Berlin November 16, 18, 1800 (1982: 76)

So Kleist wrote to his fiancé, Wilhelmine von Zenge, noting what he thought was an empirical as well as a metaphorical reflection about the optimism he felt early in their betrothal. In this compelling image of the immanently collapsing arch he inadvertently identified a trope that would recur in his writings: that of collapse. This observation by Kleist engenders the unsaid of architecture: that an arch as a technical, engineered, construction is collapse held in temporal abeyance-consequently his remark is provocative and transgressive. Kleist's seemingly empirical reflection holds in it the seeds of its own philosophical, metaphorical and material destruction. Kleist's concept of the immanently collapsing arch appears at a significant historical moment at the turn of the eighteenth century when Europe was riven by war and chaos. The arch is an object in time, it is possible to suggest that the unity of the system may ultimately fail, that it can collapse.

In Earthquake in Chile (Das Erdbeben in Chili) (1807), Kleist gives literary form to the terrain of collapse where architectural and temporal space is represented as destruction. The opening lines locate it in the real event of the 1647 earthquake in Santiago, Chile. However, the story drew on knowledge derived from accounts of the historical catastrophe of the earthquake in Lisbon sometime after 9 o'clock in the morning on All Saints Day, November 1, 1755. The epicentre was in the Atlantic west of Lisbon; recent seismologists calculate the scale close to magnitude 
nine. The earthquake, as well as the fires and tsunami that followed, left much of Lisbon and its harbour in ruins, and other places on the Atlantic coast of Portugal and Morocco were also badly affected. ${ }^{2}$ There was considerable loss of life; an estimated ten to fifteen thousand perished from a population of about $275,000 .^{3}$ The earthquake had serious consequences for Portugal's economy, which was wealthy, but badly regulated and mainly reliant on gold from its colonies in Brazil. The Lisbon earthquake caused the certainties of the Enlightenment to fragment; ${ }^{4}$ it was, after all, the destruction of a rich European capital. ${ }^{5}$ As the largest natural disaster of the eighteenth century, this event has been described by Dynes as the first "modern disaster", because its outcome disrupted progressive thinking and, importantly, it provoked action by the state to organise disaster relief and reconstruction. (SVEC 2005: 34-39) The Lisbon earthquake, while not the cause of subsequent upheavals in Western Europe, was a substantial historical marker denoting the beginning of a period of uncertainty, disorder, physical, economic and social collapse lasting 60 years - the most far-reaching being the French revolution and Napoleonic wars, which ended in 1815, four years after Kleist's suicide. The best-known representation of the earthquake is Voltaire's Candide (1759). Kendrick suggests that Candide is a satire on the demise of the "optimistic" thinking advanced by Leibniz, which is characterised by Voltaire as "tout est bien" (1956: 119-141). ${ }^{6}$ Additionally, the earthquake appeared in the work of "Sturm und Drang" writers Jakob Lenz and Johann Uz.

Shortly after making the arch observation, Kleist read Kant's critical writing and his faith in his understanding of the world collapsed. Some literary theorists have over-determined and personalised the link between this incident and the story Earthquake in Chile, confusing fiction and Kleist's state of being; for example, Frank states, "Kleist's Kant crisis was for him an intellectual and spiritual earthquake." (SVEC 2005: 268) ${ }^{7}$ For Kleist, reading Kant's critical work was a thought-changing event causing great anguish and wretchedness. But to suggest that six years later when he wrote Earthquake in Chile, he was unable to integrate that new knowledge underestimates his application and insight into Kant's critical theories. Kleist's tormented transition between empirical and critical thinking became the foundation of his writing. By early 1756 Kant wrote three essays on earthquakes, applying practical scrutiny to observations by Lisbon survivors hypothesising the cause of the calamity. ${ }^{8}$ Rather than his later critical work, it is likely Kant's earlier writings on natural phenomena led to the themes explored by Kleist.

Kant's earthquake essays consider the event only as natural philosophy and endeavour to amass scientific knowledge of earthquakes. Reinhardt and Oldroyd note Kant's opinion that in the voids under the earth and sea there was "a considerable amount of material - sulphur and iron - which could 'ferment' when acted upon by water, leading to subterranean conflagrations and upheaval of the Earth's crust" (1983: 249). ${ }^{9}$ Kant proposed a chemical explanation. Reinhardt and Oldroyd conclude that while Kant's writings on earthquakes and vulcanism did not contribute much to the development of geological understanding, their importance rests in, "Kant's manner of thinking about nature in his early, pre-critical phase, evidencing his wish to formulate a 'universal natural history" (1983: 252). The importance of identifying Kant's "pre-critical” thinking suggests the progress of hypotheses about nature was important for his development of autonomous reason. This early "pre-critical" writing has all the hallmarks of an empirical method, and represents a "scientific turn" (Larsen 2006: 362). Kant's intellectual progression from empirical observation to critique was not straightforward or unproblematic. This resonates with Kleist's trajectory after encountering Kant's 'critical' writing. Kant's essays may also be a source for the location of the story:
2 Further evidence that this was Kleist's source is Poirier (2006: 178) who notes there were not devastating fires or tsunami in Santiago in 1647, as there were in Lisbon.

3 Estimates of the fatalities vary wildly some sources suggest $60,000-70,000$ - but approx. $10,000-15,000$ is generally agreed.

4 See Kendrick 1956; Braun \& Radner 2005.

5 In 1755 Lisbon was the fourth largest city in Europe.

6 Frank notes Kendrick's 1956 discussion of Candide and the Lisbon earthquake. She notes further references connecting Kleist, Voltaire and Leibnitz by Bourke, Hamacher and Herrath, note 7 (SVEC 2005: 266).

7 Frank discusses analyses of the "Kant crisis" in her scholarly essay on Earthquake in Chile (SVEC 2005: 268-27, notes 15-21).

8 Published as: 1756 Von den Ursachen derErderschütten bei Gelegenheit de Ungücks, welches die westliche Länder von Europa gegen das Ende des vorigen Jahres betroffen hat (AK1:417-27) ('Concerning the Causes of the Terrestrial Convulsions on the Occasion of the Disaster which afflicted the Western Countries of Europe towards the End of Last Year'), 1756 Geschichte und Naturbeschreibung der Merwürdigsten Vorfälle des Erdbebens (AK1: 429-61) ('History and Natural Description of the Most Remarkable Occurrences associated with the Earthquake'), 1756 Fortgesetzte Betractung der seit einiger Zeit wahrgenommenen Erdesschütterungen (AK 1:463-72) ('Further Observation on the Terrestrial Convulsions which have been for Some Time Observed').

9 This idea is advanced by other scientists: see, for example, Nicholas Lémery. 
Chile was specifically not Lisbon; and therefore perhaps a means for Kleist distancing himself from previous representations, such as Candide. For example, Kant says "Peru and Chile are more subject to frequent quakings than all the other countries in the world." (1983: 255) Curiously, proliferation of these rapidly published personal experiences of the Lisbon earthquake did not manifest into a long-lasting collective memory of this catastrophe. The position of the 1755 Lisbon disaster in the annals of cultural history may have been displaced by the 1748 (re-) discoveries of Pompeii and Herculaneum. While more than a millennium aestheticised ancient collapse, the contemporary disaster was too close and tangible to be enshrined in the shared narratives of the time.

For Kleist, there is no special interest in contemplating the ruin as an aestheticised architectural space, but in his writing there is a deep and mordant interest in the ruination of his characters. Earthquake in Chile is a grim and violent tale of cruelty, arbitrary disaster and revenge; collapse occurs as an earthquake levels a capital city; and is mirrored in the disorder of social breakdown. Representations of space, place, and displacement, and the disruption of social order are repeating themes for Kleist. In Earthquake in Chile, architecture is spatial and political-something that can confine, conceal and be destroyed. In Kleist's writing style a relentless matter-of-factness drives the narrative: there is no concern for inner states of being. The first sentence opens:

In Santiago, the capital of the Kingdom of Chile, at the moment of the great earthquake of 1647 in which many thousands lost their lives, a young Spaniard called Jerónimo Rugera was standing beside one of the pillars in the prison to which he had been committed on a criminal charge and was about to hang himself. (1983: 51)

When Jerónimo gives up hope and contemplates suicide, a space is created into which imminence the earthquake strikes. Notably, Kleist's first paragraph parallels the opening statements of Kant's first earthquake essay, which speaks of the precariousness of architecture: "We dwell peacefully on ground the foundations of which are battered from time to time. We build unconcernedly on vaults whose pillars sometimes sway and threaten to collapse." (Reinhardt \& Oldroyd 1983: 253) Kant's hypotheses on the cause of earthquakes are based on the instability of subterranean materials leading to the possibility of collapse, and similarly as the foundation is uncertain, architecture may also be unstable.

In the story, Jerónimo's predicament occurred as tutor to Doña Josefa, the only daughter of the richest nobleman in the city. He was accused of becoming too close to her and dismissed; she then is forced into a convent, where a chance encounter in the garden allows the lovers to consummate their liaison. Subsequently Josefa has a baby, causing "an extraordinary public stir" (1983: 51). The Archbishop insists they are tried and they are condemned to death. The narrative is spatial and architectural: the father's house, the convent, the cathedral and the prison. These buildings are the family, the church and the law. Kleist demonstrates the prurient interest in an aristocratic execution: "In the streets through which the culprit was to be led to her execution the windows were rented, the roofs of the houses were partly dismantled." (1983: 52) The earthquake destroys this morbid and grotesque spectacle. Meanwhile, Jerónimo's desperation is delineated by the insurmountable architecture of his confinement: locks, bars, and walls. He hears the bell toll for Josefa's execution. Time is desperately poised between immanence and advancement, "when suddenly, with a crash as if the very firmament had shattered, 
the greater part of the city collapsed, burying every living thing beneath its ruins" (1983: 52). The moment of the earthquake inverts Jerónimo's circumstances from certain death to seizing life:

... great cracks appeared in the walls all round him, the whole edifice toppled towards the street and would have crashed down in to it had not its slow fall been met by that of the house opposite, and only the arch thus formed by chance prevented its complete destruction. (1983: 53)

This is simultaneously experienced and observed by the horror-struck Jerónimo as he witnesses the progression of the collapse of the prison: the frightful circumstance of the earthquake has made time stand still. The "arch formed" by the random disaster creates a threshold through which Jerónimo survives and escapes, demonstrating how architecture can be remade by the cataclysm of collapse.

Earthquakes in cities, towns or villages are massive architectural events. Kleist has depicted the consequences of an earthquake on a city and its inhabitants with considerable understanding, which could only come from reading first-hand accounts by survivors. Kleist describes the kind of death and destruction occurring with earthquake, where crushing, entrapment, burning and drowning, cause most of the casualties - circumstances well documented in Lisbon in 1755. Kleist identifies the concept of separate tremors ${ }^{10}$ within the earthquake and these become temporal spaces momentarily inhabited by the narrative. Jerónimo darts and weaves through the collapsing Santiago, which is represented as an architecture in turmoil. In the moments following the earthquake, Kleist changes time from the linear movement of the tolling bell, to one of simultaneity. Returning to Kleist's observation concerning the arch which "remains standing ... because all the stones tend to collapse at the same time" (1982: 76) the earthquake has caused the city to behave as if it were the arch collapsing, where collapse occurs "at the same time". In his essay on the Lisbon earthquake Benjamin quotes an English survivor:

There was a shattering noise, as if all the buildings in town were collapsing at the same time ... I truly thought my last moment had arrived, for the walls were bursting apart and great stones were falling out of the joints - all the beams seemed to be supported by thin air. (1999: 539)

These comments parallel Kleist's description. In a contemporary German engraving depicting the aftermath of the Lisbon earthquake of 1755 (Fig.1) the background shows the effect of the earthquake on architecture; buildings are without roofs, and among the tidy debris the striking and repeated visual motif is that of the arch shown as both an architectural survivor of the destruction, and as the strange image of half-arches in the air in a state of partial collapse.

Jerónimo reaches the rural outskirts, faints in exhaustion, regains consciousness, and sees Josefa who has escaped execution and rescued their baby from the convent: "She was just about to embrace the Abbess when the latter was ignominiously struck dead by a falling gable, together with nearly all her nuns.” (1983: 56) The death of both the merciful Abbess and the Archbishop who condemned them to death, highlights the contradiction that good and bad are killed by the earthquake. The fact that in Lisbon casualties occurred while congregations were worshipping on All Saints Day in 1755 caused consternation for the church, which avowed that the earthquake was God's retribution on a godless city. Following the earthquake, the surviving populace fled the city en masse. Kendrick notes that

10 Kant did not deduce the concept of separate shocks from his analysis of Lisbon survivors' accounts. 
Fig. 1 The Ruins of Lisbon (1755) German copperplate engraving, artist unknown. [Source: National Information Service of Earthquake Engineering (NISEE), University of California, Berkeley] there was a "desperate scramble to get out of Lisbon by frightened mobs of hysterical people, clutching crucifixes and images of saints, and bits and pieces of belongings, all trying to reach open country" (1956: 36-37). Outside Lisbon, people lived for many months in tents and huts, too frightened to dwell in anything more substantial: the open country offered a sense of safety from precarious architecture. Even the royal family were not exempt from this abject fear, they evacuated into tents for nine months, subsequently moving into a large wooden lodging, itself another provisional structure. In The Ruin of Lisbon 1755 (Fig.1) the foreground shows the establishment of a tightly-packed makeshift tent city. Survivors are carrying large bundles to the tents, families are in various states of activity or immobility, people with arms raised are imploring heaven, and one woman is caught as she falls in a faint; in the upper left background of the engraving figures are shown still escaping the devastated city.

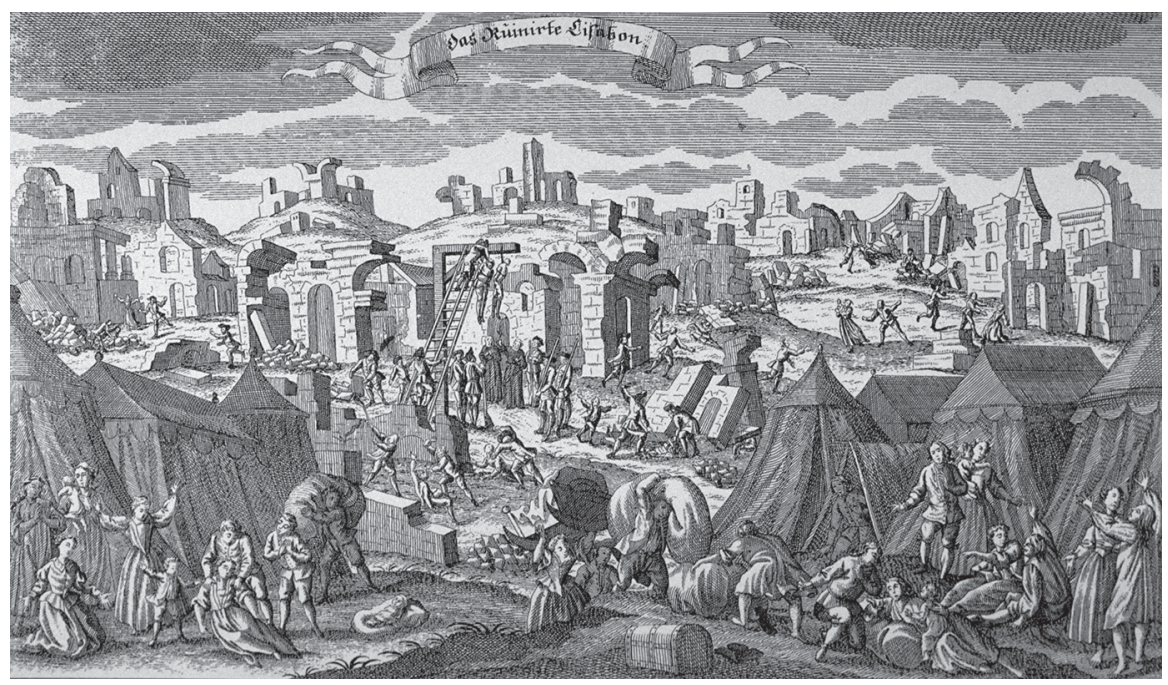

While sheltering in the forest, the lovers meet an aristocratic acquaintance of Josefa's and are taken into Don Fernando's family. Following the earthquake they hope there might be a "spirit of reconciliation" (1983: 59). At a Mass in the only church left standing, the canon decries the prior "outrage" in the convent garden, declaring the sinners' souls should be consigned to hell, "pointing to a crack in the wall of the cathedral, he called yesterday's earthquake a mere foretaste of doom" (1983: 63). The cracked cathedral presages disaster for the church; the damage is architectural and political. The priests stand by as the congregation becomes a vengeful, frenzied mob-Jerónimo's father identifies and kills him, Josefa is slain by her family's cobbler who persists until he "seized one of the infants by its legs after whirling round in the air above his head, dashed it against the edge of one of the pillars of the church" (1983: 67). Thus the deaths of Jerónimo, Josefa, their friends, and mistakenly, the child of Don Fernando are absorbed into the fabric of the church. In this murderous outcome to Earthquake in Chile, Kleist identifies the Catholic Church as a social order that can itself collapse. Within days of the earthquake in Lisbon, in order to establish power over a frenzied populace, and to prevent opportunistic looting, the state executed as many as 35 people (Kendrick 1956: 50). A grim demonstration of this can be seen in the middle ground of the The Ruin of Lisbon (Fig. 1) where two figures are shown being strung up on a gibbet. 
In his 1763 essay, 'The only possible argument in support of a demonstration of the existence of God' Kant again refers to earthquakes, emphasising:

... the wickedness of a city has no effect upon the fires concealed within the bowels of the earth ... the event in question was a misfortune, not a punishment: man's moral conduct cannot be a cause of earthquakes according to a natural law, for there is no connection here between the cause and the effect. (1992: 147)

In Earthquake in Chile, Kleist follows Kant's logic, demonstrating that the lovers are not really wicked, do not deserve to be punished by the church, that their moral laxity is not to blame for the earthquake. The random collapse of Santiago created provisional architectures made by the earthquake and, briefly, the disaster provided the protagonists with a means of escaping their fate. The lovers grasp on to life, only to die in the collapse of the society itself. At the centre of this catastrophe Kleist creates a paradox: at the very moment of the collapse of the prison walls an arch is created, and instead of falling down, a structure and a space is made. By considering the 1755 Lisbon earthquake, Kant's earthquake essays and Kleist's story together, the destruction of foundations of thought and space can be linked to the material disruption of collapse.

\section{The second terrain}

\section{Portland: material, landscape, collapse}

In the second and most substantial of the 1756 earthquake essays Kant clarifies his concern with the material ground affected by earthquake: "We know pretty completely the surface of the earth, when the ampliation* is concerned. But we have under our feet a world still, with which we at present are but little acquainted." $(1799: 96)^{11}$

The question as to what lay beneath has parallels with emerging theories of the earth in the seventeenth century ${ }^{12}$ which were revived by the Lisbon earthquake. Kant identifies the limits of knowledge about what exists at a deeper structural and material level. Concurrently, these inquiries began to focus on the substance of the earth. James Hutton (1726-1797) published his first geological observations in 1785, Theory of the Earth, identifying geological time by suggesting layers were incrementally formed over vast periods; later geological thinking took a different turn with Georges Cuvier (1769-1832), who proposed the idea of extinction after comparing the anatomy of living and fossilised vertebrates. The cultural context in which Cuvier advanced his hypothesis of "catastrophism" in Essay on the Theory of the Earth (1812), lay in the aftermath of the Lisbon earthquake and the contemporary turmoil in France. An adherent of Cuvier's catastrophism, William Smith, a West Country surveyor excavating canals, noticed that the layers of fossils in stone could identify strata, and lead to the first geological map of Britain. The fossil material in Jurassic limestone from the Dorset coast was key to his project. Smith's 1815 geological map was the first of its kind; by mapping strata, he charted volume rather than surface and consequently, he mapped space and time.

Portland, on the Dorset coast, is a landscape of disruption, a site made by architecture's uses, and as such demonstrates images of collapse in space, time,
11 Translator's note: Enlargement of knowledge, in contradistinction to exactness: extension opposed to intension. (1799: 96)

12 Kant wasn't proposing a theory of the earth as advanced in the seventeenth century. See Burnet 1635-1715; Leibniz Protogaea 1693; Hooke's second lecture series 1667-1668; Oldroyd 2006: 25, 30, 36 
Fig. 2 Portland : London (Cheyne Weare/Greenwich Hospital) [Photos: author, 2011] material and topography. Portland's landscape materialises Kleist's vision of collapse. Malpas and Thiel identify the spaces and boundaries of Kantian geography: "The manner in which Kant characterizes the idea of boundary invokes the geographical ... but Kant's characterization is also explicitly topographical inasmuch as the idea of boundary is directly connected with the idea of a location or place." (2011: 198)

The volumes of fossils that comprise Portland stone are also boundaries of chthonian histories, dead creatures falling to the bottom of a warm sea as life collapses in time. Recurrent costal landslips exposed the strata of Portland's Jurassic limestone, showing its potential as architectural material. Four centuries of quarrying have left Portland scarred by dislocation and absence. Portland's landscape has been created by the removal of its stone: it is a built environment made from the voids left by quarrying. This site has been studied as an unstable space of collapse giving material, architectural, historical and literary representations of these eighteenth-century ideas suggested by Kleist and Kant.

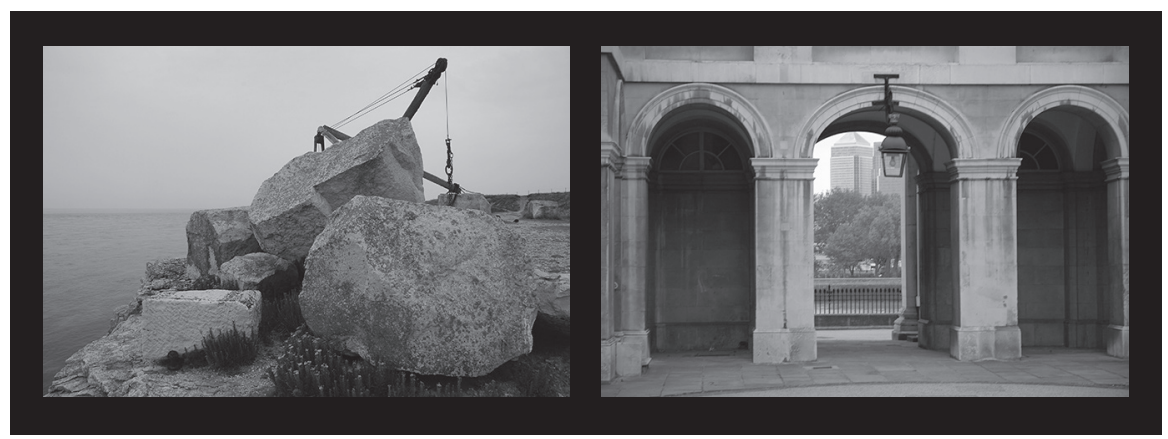

... he sometimes cast his eye across the Thames to the wharves on the south side, and to that particular one whereat his father's tons of freestone were daily landed from the ketches of the south coast. He could occasionally discern the white blocks lying there, vast cubes so persistently nibbled by his parent from his island rock in the English Channel that it seemed as if in time it would be nibbled all away (1997: 41).

In The Well-Beloved (1897), Thomas Hardy describes stone arriving from his fictional Portland, 'Isle of Slingers'. Hardy captures the incremental disappearance and shrinkage of the island, as the stone is carted away piece by piece the island may collapse in on itself, buried under leftover rubble, becoming its own cenotaph. Portland is characterised as an uncertain place, always changing as another absence is made. Portland has been a working, industrial site since the late seventeenth century, pre-dating the Industrial Revolution; the quarrymen have worked to provide stone for the architect, artist and artisan. The spaces left behind by quarrying are a reminder that taking material in order to build or fabricate is in itself not only an act of construction but also the generation of surplus.

A distinctive feature of Portland's landscape is the collapsed material from the cliffs, called "weares". Brunsden et al noted that "27\% of Portland is affected by landslips (c. 317 ha out of a total area of $c .1130$ ha) this includes most of the coastal fringe", adding that there have been 72 landslips since the earliest recorded landslip in 1615. Their study points out that Portland's coast has the greatest number of landslides in Britain (1996: 214). Distinct horizontal sedimentary layers with vertical joints characterise limestone; this is both advantageous and dangerous for 
quarrying, as the joints can facilitate the removal of stone, but are also unstable. A proportion of existing buildings on the island have structural problems. Brunsden et al outline how the geomorphology of Portland further adds to the propensity for the joints or "gullies" in the limestone to enlarge and weaken, causing coastal collapse. This geology of landslip links with Paul Carter's thoughts on the study of coasts:

The coast was primarily conceived as an arena of intellectual inquiry; in this form it was the line that enabled the scientist to draw other lines.... Its very disarray, the mimic resemblance of its productions to the specimens arranged in a cabinet de curiosités ... suggested a museum in the making. (2002: 132)

Carter creates an evocative picture of the relationship of science to the delineation of coasts as both real and abstract, suggesting that coasts, as edges under constant battering by the sea, elude fixity. Portland as a site is contradictory: an island that is not an island, there is a paradox in the durability of the stone against the instability of the cliffs. Portland is a terrain of scars; quarrying has irretrievably changed the topography of the island. The term "weares" also applies to layers of debris at the quarries, and used as partial infill across the island. The "weares" look as though something has collapsed, that disaster has occurred, like a battlefield; but the "weares" are also constructed, the abandoned rubble making unintended, random sculptures, abstract arrangements from the piles of stone.

Architects chose Portland stone for its durability as a fine-grained oolitic limestone. Inigo Jones chose Portland stone to stand in for the whiteness of classicism, whereas Christopher Wren used it for its intrinsic qualities. A series of significant historical disasters accelerated the wholesale requisition of Portland stone: best known is the reconstruction after the Great Fire of London in 1666. Using Portland stone as the primary material, Wren rebuilt more than 50 churches, as well as St Paul's Cathedral completed in 1710. A large coastal landslide in 1636 made the stone workable from Portland's northeast cliff and Wren took six million tons of stone for the rebuilding of London. Less acknowledged is the use of Portland stone for war memorials following the First and Second World Wars; it was the principal material for gravestones and memorials for the missing dead because it was reliable, cheap, and-importantly-British. The process of quarrying created a series of double absences: where quarries were constructed absences and the use of stone for architecture and memorials was a manifestation of absence made material. In order to commemorate the absent body, absence was created by the removal of the stone. Distributed in foreign fields around the world, there are between 700,000 and 800,000 grave markers of Portland stone.

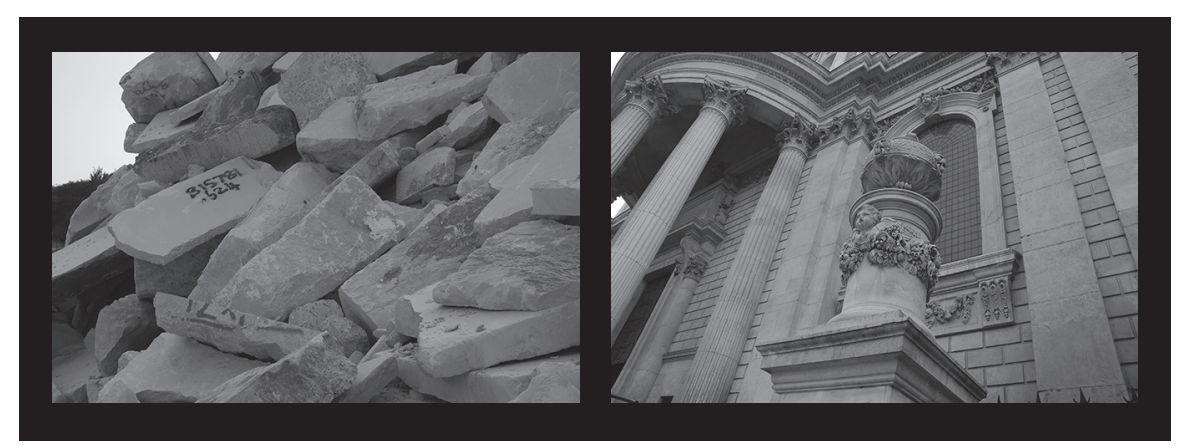

Fig. 3 Portland: London (Independent Quarry/St Pauls Cathedral) [Photos: author 2011] 
Fig. 4 Portland: London (Independent Quarry/Waterloo Bridge) [Photos: author 2011]
The landscape of the quarries is a built environment constructed from the voids of absent stone: it is the negative space of architecture, but there are no architects or builders present in their construction. The walls of the quarries-scarred by drills, cutters and saws-show the history of quarrying, and the geological strata exposed evoke the levels of a building. At the abandoned and working quarries space is a remainder: a history, it is both the absent material and the material absence and, as such, space becomes something; at the quarries space is made. This slightly diverges from Kant:

One can never represent that there is no space, although one can very well think that that there are no objects to be encountered in it. It is therefore to be regarded as the condition of the possibility of appearances, not as a determination dependent on them. (1998: 158)

And rather than the immanence of "appearances" an image is suggested here from the "possibility" of absences. Kant suggests that space is the outward appearance of possibility, of something impending, that in the future something might come into being; however, this does not necessarily have to be an actual form, though this is not absolutely ruled out. The sheer scale of the space left behind compels the viewer of the quarry to re-imagine the stone that has been taken, to re-build the landscape out of the absent blocks of free stone, looking into these big, dusty voids and debris it is possible to generate images of architecture over the emptiness, to make images and objects in the spaces of the quarries and to trace in the absent blocks of stone.

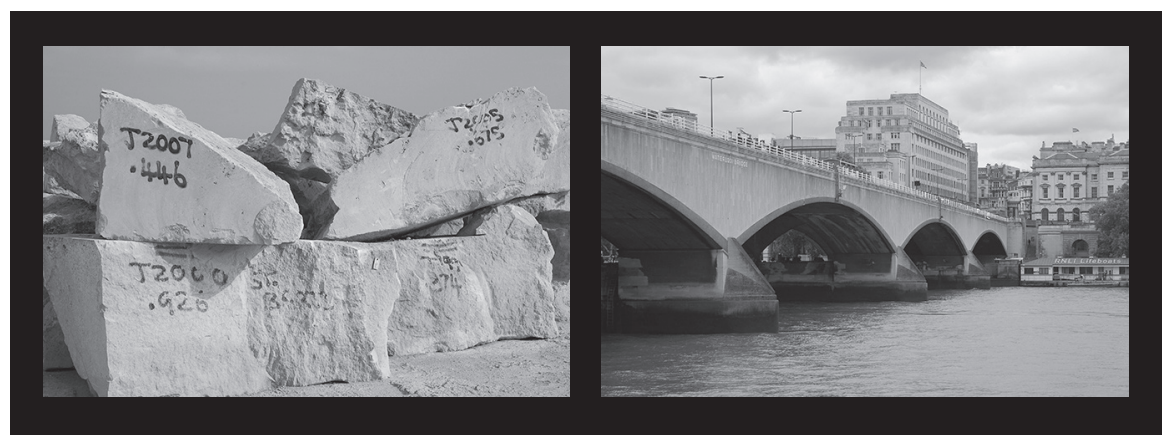

\section{Conclusion}

The theme of collapse suggests a premise for tracing a route towards modernist thought. Kleist's observation that an arch is only held in place because all the stones want to collapse at the same time is a compelling image-that the arch only stands because it wants to collapse. For Kleist collapse also came about by reading Kant's critical writing and the loss of the certainty of empirical observation. In Earthquake in Chile, Kleist turned to the historical event of the disastrous 1755 Lisbon earthquake, using this source to represent disruption and collapse of architecture and social order. Kant's response to the earthquake was a defining moment and contributed to the foundation of his critical thinking. The Lisbon earthquake revived research questioning what is beneath the earth's surface and why it may fail-leading to critical developments in geology and the history of science. Focussing on the site of Portland as one of convergent histories of architecture, geology, 
and material in the eighteenth century, I argued that this disrupted landscape demonstrates Kleist's notion of immanent and actual collapse. In the histories of the fragmentation and reconfiguration of European thought at the end of the eighteenth and at the beginning of the nineteenth centuries, Kleist's image of collapse generates a recognisable image of modernity.

\section{References}

Benjamin, W. (1999). Selected writings volume 2 1927-1934 (Rodney Livingstone et al. Trans.). Cambridge, Mass.: Belknap Press, Harvard University.

Braun, T. E. \& Radner, J. (Eds.). (2005) The Lisbon earthquake of 1755: Representations and reactions. Studies on Voltaire and the Eighteenth Century SEVC, 02.

Oxford: The Voltaire Foundation.

Brundsen, D., Coombe, K., Goudie, A. S. \& Parker, A. G. (1996). The structural morphology of the Isle of Portland southern England. Proceedings of the Geologists' Association, No.107, 209-230.

Carter, P. (2002). Dark with excess of bright: Mapping the coastlines of knowledge. In D. Cosgrove (Ed.), Mappings. London: Reaktion Books.

Dynes, R. (2005). The Lisbon earthquake of 1755: The first modern disaster. In T. Braun and J.

Radner (Eds.), The Lisbon earthquake of 1755: Representations and reactions. Studies on Voltaire and the Eighteenth Century (SVEC 2005: 02). Oxford: The Voltaire Foundation.

Frank, L. No way out: Heinrich von Kleist's Erdbeben in Chile, in T. Braun and J. Radner (Eds.), The Lisbon earthquake of 1755: Representations and reactions, Studies on Voltaire and the Eighteenth Century (SVEC 2005:02). Oxford: The Voltaire Foundation.

Hardy, T. (1997). The well-beloved. London: Everyman Paperbacks.

Kant, E. (1799). Essays and treatises on moral, political, religious and various philosophical subjects (from the German by the translator of the Principles of Critical Philosophy), Vol. II. London: William Richardson Royal Exchange.

Kant, I. (1998). Critique of pure reason (P. Guyer \& A. Wood, Trans.). Cambridge: Cambridge University Press.

Kant, I. (1992). Theoretical philosophy 1755-1770 (D. Walford Ed. \& Trans.). Cambridge: Cambridge University Press.

Kendrick, T. D. (1956). The Lisbon earthquake. London: Methuen.

Kendrick, T. D. (1956) The Lisbon earthquake, in T. E. Braun \& J. Radner (Eds.), The Lisbon earthquake of 1755: Representations and reactions. Studies on Voltaire and the Eighteenth Century (SVEC 2005: 02). Oxford: The Voltaire Foundation.

Kleist, H. von. (1982). An abyss deep enough: Letters of Heinrich von Kleist (P. B. Miller, Ed. \& Trans.). New York, NY: E. P. Dutton.

Kleist, H. von. (1983). The Marquise of O - and other stories (D. Luke \& N. Reeves, Trans.).

London: Penguin.

Larsen, S. E. (2006). European Review, Vol. 14, No 3, p. 359-367.

Malpas, J., \& Thiel, K. (2011). Kant's geography of reason. In S. Elden \& E. Mendieta (Eds.), Reading Kant's geography (pp. 195-214). Albany, NY: State University of New York Press.

Poirier, J.-P. (2006). European Review, Vol. 14, No 2, p. 169-180.

Reinhardt, O. \& Oldroyd, D. R. (1983). Kant's theory of earthquake and volcanic action. Annals of Science, No. 40, p. 247-272.

Voltaire. (2001). Candide. London: Penguin. 